Review

\title{
Theranostic Impact of NG2/CSPG4 Proteoglycan in Cancer
}

\author{
Pier Andrea Nicolosi ${ }^{1}$, Alice Dallatomasina ${ }^{2}$ and Roberto Perris $1,2,3 \rrbracket$ \\ 1. Department of Experimental Oncology 2, National Tumour Institute Aviano, CRO-IRCCS, Via Franco Gallini 2, 33081 AVIANO (PN), Italy; \\ 2. COMT - Centre for Molecular and Translational Oncology; \\ 3. Department of Life Sciences, University of Parma, Parco Area delle Scienze 11/A, 43124 PARMA, Italy.
}

$\triangle$ Corresponding author: Roberto Perris, Phone: +39-0521-906601 +39-0434-659760 Fax: +39-0521-906019 Email: panicolosi@cro.it or rperris@cro.it.

(C) 2015 Ivyspring International Publisher. Reproduction is permitted for personal, noncommercial use, provided that the article is in whole, unmodified, and properly cited. See http:/ /ivyspring.com/terms for terms and conditions.

Received: 2014.10.16; Accepted: 2014.12.03; Published: 2015.02.15

\begin{abstract}
NG2/CSPG4 is an unusual cell-membrane integral proteoglycan widely recognized to be a prognostic factor, a valuable tool for ex vivo and non-invasive molecular diagnostics and, by virtue of its tight association with malignancy, a tantalizing therapeutic target in several tumour types. Although the biology behind its involvement in cancer progression needs to be better understood, implementation of NG2/CSPG4 in the routine clinical practice is attainable and has the potential to contribute to an improved individualized management of cancer patients. In this context, its polymorphic nature seems to be particularly valuable in the effort to standardize informative diagnostic procedures and consolidate forcible immunotherapeutic treatment strategies. We discuss here the underpinnings for this potential and highlight the benefits of taking advantage of the intra-tumour and inter-patient variability in the regulation of NG2/CSPG4 expression. We envision that NG2/CSPG4 may effectively be exploited in therapeutic interventions aimed at averting resistance to target therapy agents and at interfering with secondary lesion formation and/or tumour recurrence.
\end{abstract}

Key words: NG2, CSPG4, proteoglycan, cancer

\section{Structural-functional features of NG2/CSPG4}

NG2/CSPG4 is a unique, multivalent transmembrane proteoglycan (PG) accountable for many of the interactions taking place between cancer cells and their microenvironment to promote the myriad of cellular events propagating tumour growth and spreading (Fig. 1; [1-5]). It was originally identified on the surface of cutaneous melanoma cells, as part of a repertoire of immune-dominant antigens characteristic of these neoplastic cells [6-11], and because of its large size was named High Molecular Weight Melanoma-Associated Antigen (HMW-MAA or simply Melanoma Cell Surface Proteoglycan - MCSP). Coincidently, the same molecule was disclosed to be implicated in neuron-glial interactions in the rodent $\mathrm{CNS}$ and was accordingly named Neuron-Glia Protein 2 (NG2;[12]). Following cloning of the rodent orthologue [13], the human NG2 gene (CSPG4; [14]) was pinpointed to chromosome 15:24q2 [15] and shown to encode for a $8.9 \mathrm{~kb}$ transcript with an open reading frame of 8,071 nucleotides which translates into a core protein of 2,322 residues. This polypeptide encompasses numerous glycosylation sites and three putative glycosaminoglycan (GAG)-attachment sites, yielding the potential to generate a molecule of $>500 \mathrm{kDa}$. Owing to its extended extracellular domain, NG2/CSPG4 has the potential to engage in a multitude of molecular interactions, spanning from sequestration of growth factors, signalling molecules and metalloproteinases to binding to cell surface receptors for these ligands 
and to the ECM (Fig. 1).

In highly motile cells, such as cancer cells, NG2/CSPG4 accumulates in the advancing cytoplasmic front, in filopodial extensions and at cell-substratum contact areas (Fig. 1). Extracellular cleavage of the molecule contributes to both the physiological and disease-associated fragmentation of the extracellular domain by a cell-autonomous signal transduction-dependent mechanism. Tryptic products of the PG have been widely described [16, 17], but these ectodomain fragments still lack a precise homeostatic or pathological function. There is similarly remarkably scanty information about the glycosylation/glycanation patterns of NG2/CSPG4 molecules expressed by healthy and cancer tissues and how these may be related to the PG's structural-functional diversities. The cytoplasmic tail of NG2/CSPG4 contains two threonine residues undergoing differential phosphorylation by PKC $\alpha \quad\left(\mathrm{Thr}^{2256}\right)$ and ERK(s) $\left(\mathrm{Thr}^{2314}\right)$ depending upon the cellular events in which the PG may participate [18, 19]. Through PDZ-type adaptor proteins, such as MUPP1 and synthenin-1, the intracellular domain of NG2/CSPG4 links to the actin cytoskeleton, in part also via a close association with ezrin and cofilin-1. These cytoskeletal connections and the above mentioned PKC/ERK-regulated threonine phosphorylations activate a number of signalling effectors including FAK, PI-3K, Akt1, Rac1, cdc42, Ack1 and p130cAS [18-24]. The inter-relationship between NG2/CSPG4 and these sig- nal transducers and its functional implication is gradually being resolved.

Tissue distribution of NG2/CSPG4 is wider than that originally thought, but still prevails on discrete premature cells prone to originate tumours

It was originally suggested that the expression pattern of NG2/CSPG4 was restricted to a limited number of tissues, with a certain prevalence for the CNS and "immature cell phenotypes" [25-27]. With the advent of more specific reagents to capable of detecting the PG in situ, its expression has progressively been documented in a larger proportion of human tissues, where it seems to be proper of cell types not necessarily representing the most immature ones of that given tissue/anatomical district. According to information retrievable from the literature, from publicly accessible data bases, and from our own immune-mapping studies, NG2/CSPG4 is highly expressed in $>10$ tissues/organs of the adult human body (brain, gastrointestinal tract, endocrine organs), but, remarkably, in many of these tissue/organs there is an enigmatic poor correlation between transcript and protein levels. Despite its fairly wide expression pattern (>50 cell types), in most anatomical sites, NG2/CSPG4 appears indeed characteristic of precursor/progenitor cells, including putative stem/progenitor cells of both epithelial and mesodermal origin [28-39].

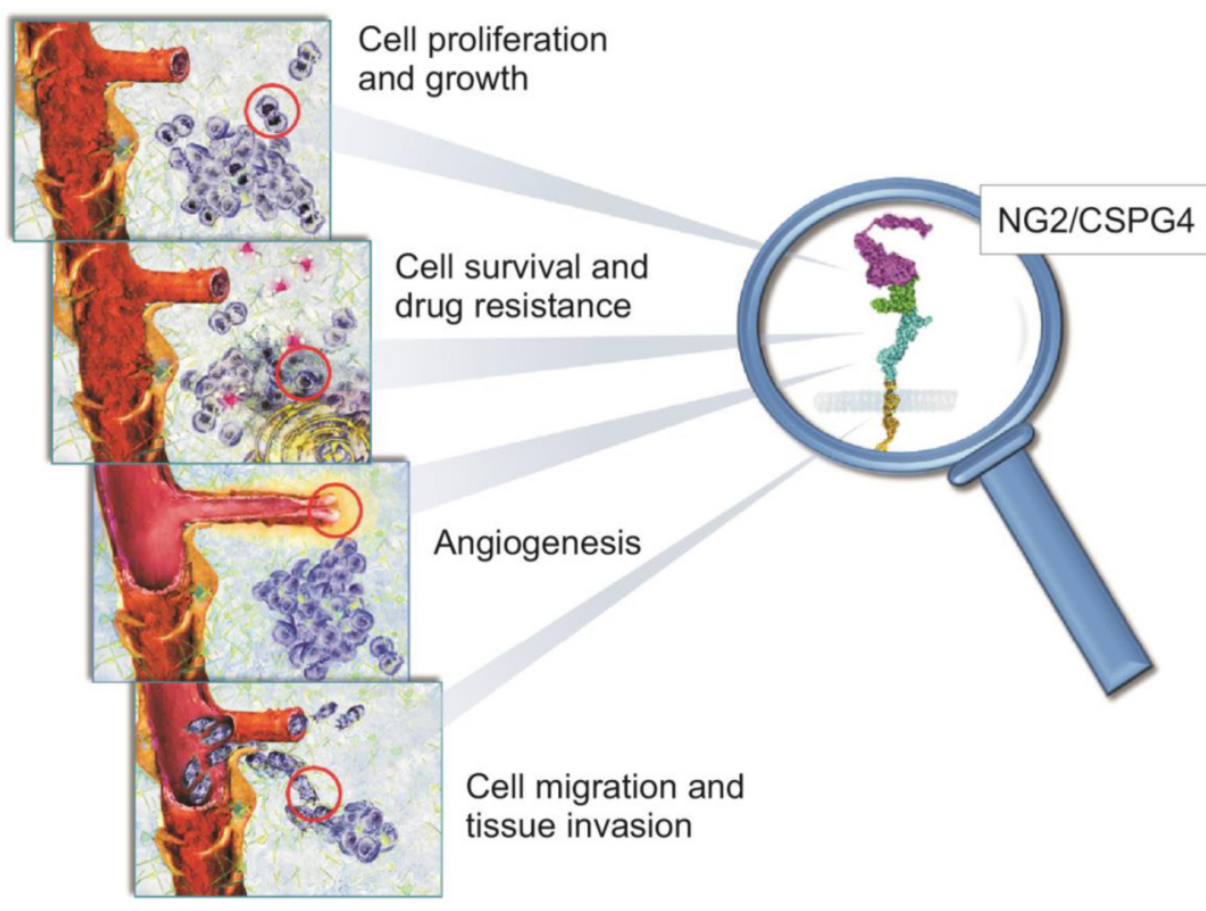

Figure 1. Schematic portrayal of the involvement of NG2/CSPG4 in biological phenomena known to be pivotal in the regulation of tumour growth and spreading. There is solid experimental evidence for a primary role of NG2/CSPG4 in mediating the tumour cells' interactions with their microenvironmental ECM. Through its capability to sequester various growth factors and modulate the activity of their cognate receptors, NG2/CSPG4 directly controls cancer cell proliferation (upper panel). Cells overexpressing NG2/CSPG4 up-regulate signalling pathways associated with cell survival (i.e. the PI-3K-mTOR-Aktl-PTEN axis) and attain a pronounced resistance to both conventional and target therapy drugs, as as well to radiation therapy (middle upper panel). NG2/CSPG4 is a primary pericyte marker and it acts as a primary regulator of angiogenesis. In fact, it serves as a mediator of pericyte activation and thereby as a promoter of angiogenic sprouting (lower middle panel). Its ability to interact with ECM, alongside with the ability to modulate the activity of multiple integrins and metalloproteinases, allow NG2/CSPG4 to be tightly implicated in the control of cancer cell movement and invasion. This includes the entrance and exit of disseminating cancer cells from the haematic and lymphatic circuits (lower panel). 


\section{Upregulation of NG2/CSPG4 is a frequent event of neoplastic progression, but its di- agnostic utility is clinically overlooked - why is that?}

There is currently no information on amplifications of chromosome 15:24q [40], or any other genetic anomaly (e.g. chromosomal translocation, gene deletion, exon skipping, etc) involving the NG2/CSPG4 gene and/or causing alterations in the expression of the PG in diseased cells. Analogously, NG2/CSPG4 has not been identified as a factor directly promoting tumour formation, but has been shown to become de novo expressed in a number of solid and haematological neoplastic conditions, as well as to be linked to cancer-associated epithelial-mesenchymal transitions [3]. The most striking examples of this latter transitional linkage are the appearance of NG2/CSPG4 on melanoma cells, breast, head and neck carcinomas and mesotheliomas ([41-43]; Rossi et al., submitted). Conversely, in mesenchymal tumours the relationship between NG2/CSPG4 expression and neoplastic transformation is different: NG2/CSPG4 is constitutive of the mesenchymal progenitor/stem cells $[35,39]$ from which sarcomas are thought to originate [44] and becomes progressively upregulated with increasing malignancy $[24,45]$. The remarkable inter-patient and intra-lesional variability in de novo expression/upregulation of NG2/CSPG4 remains puzzling and has not found a clear explanation. Similarly, it remains to be uncovered to what extent the functions exerted by NG2/CSPG4 on healthy and cancer cells actually coincide.

Even though high transcriptional levels of the CSPG4 gene may be detected, appearance of PG on the surface of cancer cells may not always occur (i.e. the PG is primary detected intracellularly) and is likely to be a mere secondary event of tumour formation. It may therefore not be entirely unexpected to obtain confounding results from studies on autochthonous murine cancer models. For instance, experimentally induced cerebral tumours, i.e. elicited by ectopic expression of the PDGF proto-oncogene in the developing mouse brain $[46,47]$, have been observed to form equally well in the total absence of NG2/CSPG4 [48]. Somewhat unpredictable was, however, the discovery that, in spite of the well-documented role of NG2/CSPG4 in PDGF signalling [29, 49-52], PDGF-induced gliomas not only originated with the same frequency, but also progressed to the same extent in the NG2/CSPG4 null background as in wild type animals [48]. A clear-cut explanation for this apparent inconsistency has not yet been provided, but differences in experimental models and biological contexts within which the
NG2/CSPG4 involvement in PDGF signalling has been documented may be the ground for the discrepancy. An alluring possibility may further be that the NG2/CSPG4 contribution to the cells' responses to PDGF is dose-related: at optimal ratios of NG2/CSPG4 molecules versus available PDGF ligand in proximity of the cell surface, the PG exerts a precise co-receptor function. By contrast, when the growth factor molecules reaches the cell membrane at outnumbering amounts compared to the available NG2/CSPG4 surface molecules, then the co-receptor role of the PG is strongly attenuated, or even bypassed. Such scenario would be coherent with a discrete docking receptor function of NG2/CSPG4, acting within the framework of the "absolute model" of morphogen gradient-perception [53], as we have recently underscored for the involvement of NG2/CSPG4 in FGF signalling [52].

Gene profiling data accrued during the years and a wide spectrum of immunochemical studies, have thoroughly substantiated the enhanced expression of NG2/CSPG4 in several cancer types (Table 1; Fig. 2). At present, augmented transcriptional and/or translational levels of NG2/CSPG4 have been disclosed in 34 solid tumour types (and their subvariants) $[8,41-43,45,54-73]$, and, in several of them, a certain diagnostic and/or prognostic connotation of the PG has been proposed (Table 1; Fig. 3). A wealth of studies have additionally indicated the potential value of NG2/CSPG4 (alone or in combination with other antigens) in disclosing occult and/or micro-metastases by histology and diagnostic whole-body imaging [74-82]. Meanwhile, corollary investigations have underscored the usefulness of the PG as a marker for circulating cancer cells in melanoma patients (Fig. 2; [83-89]); a similar potential is expectable for other solid tumours exhibiting abundant NG2/CSPG4 expression levels.

Notably, in several solid tumours, NG2/CSPG4 is more abundant and more homogeneously distributed in metastatic lesions than in the primary tumour masses [24, 43, 45, 57, 59, 67, 68, 90]. This would suggest that the PG may drive metastasis formation, as proposed by some experimental data in the mouse [42, 70, 91-93]. Obviously, it is technically impossible to determine whether NG2/CSPG4 overexpressing cells of primary lesions actually are the ones fated to give rise to metastases, because of a destiny imparted by the action of NG2/CSPG4, or whether malignant cells forming metastases simply upregulate the PG site-specifically. In this latter case, upregulation of NG2/CSPG4 should be considered to be a tertiary tumorigenic event, whose significance remains to be investigated. A comprehensive picture of the relative distribution and frequency of NG2/CSPG4- 
expressing subpopulations of cells constituting primary versus secondary lesions also remains to be determined, leaving thereby unresolved to what extent NG2/CSPG4-enriched cancer cell subsets may influence metastasis formation. Furthermore, although cells engineered to overexpress NG2/CSPG4 are generally more malignant than their counterpart NG2/CSPG4-deficient cells [42, 43, 91, 92], unequivocal experimental proof of a direct metasta- sis-promoting effect of the PG is currently missing. It is, however, interesting to note that enhanced expression of NG2/CSPG4 in primary lesions of oral cavity carcinomas strongly predicts tumour recurrence (Rossi et al., submitted; Table 1). This adds to the theranostic value of the PG, as it identifies a patient subgroup that may benefit from an NG2/CSPG4-targeted therapeutic approach.

Table 1. Diagnostic-prognostic implications of NG2/CSPG4 expression in solid tumours 1

\begin{tabular}{|c|c|c|c|c|c|c|}
\hline Tumour type ${ }^{2}$ & Primary $^{2}$ & Metastasis & Prognosis & Transcript $^{3}$ & Protein (antibody) ${ }^{4}$ & Reference \\
\hline \multicolumn{7}{|l|}{ Soft tissue sarcomas } \\
\hline Fibrosarcoma & $100 \%$ & $100 \%$ & OS, MetP & qPCR & $\mathrm{IHC}, \mathrm{Ab} \mathrm{D} 2$ & {$[24,46]$} \\
\hline Leiomyosarcoma ${ }^{5}$ & $100 \%$ & $100 \%$ & OS, MetP & qPCR & $\mathrm{IHC}, \mathrm{Ab} \mathrm{D} 2$ & {$[24,46]$} \\
\hline Pleomorphic & $100 \%$ & $100 \%$ & OS, MetP & qPCR & $\mathrm{IHC}, \mathrm{Ab} \mathrm{D} 2$ & {$[24,46]$} \\
\hline Liposarcoma $^{6}$ & $100 \%$ & $100 \%$ & OS, MetP & qPCR & $\mathrm{IHC}, \mathrm{Ab} \mathrm{D} 2$ & {$[24,46]$} \\
\hline Synovial & $100 \%$ & $100 \%$ & OS, MetP & qPCR & $\mathrm{IHC}, \mathrm{Ab} \mathrm{D} 2$ & {$[24,46]$} \\
\hline Chondrosarcoma & $48 \%$ & Unknown & Unknown & qPCR & IHC, mAbs 63.74, VF1-TP41.2, VT80.12 & [66] \\
\hline \multicolumn{7}{|l|}{ Cerebral tumours } \\
\hline Glioblastoma & $20-100 \%$ & Unknown & DP, OS & $\begin{array}{l}\text { qPCR, } \\
\text { whole-genome } \\
\text { arrays }\end{array}$ & $\begin{array}{l}\text { IHC, FACS,WB, Ab D2; mAbs 9.2.27, } \\
\text { N143, N109, N92 }\end{array}$ & $\begin{array}{l}{[1,57,61} \\
62,70,71]\end{array}$ \\
\hline \multicolumn{7}{|l|}{ Bone tumours } \\
\hline Chordoma & $62 \%$ & Unknown & Unknown & qPCR & IHC, mAbs 763.74, VF1-TP41.2, VT80.12 & {$[66]$} \\
\hline \multicolumn{7}{|l|}{ Breast carcinomas } \\
\hline TNBC & $73 \%$ & $86 \%$ & Unknown & Data base ${ }^{7}$ & $\mathrm{IHC}, \mathrm{mAb} 225.28$ & [43] \\
\hline ER+ & $40 \%$ & Unknown & Unknown & Data base & $\mathrm{IHC}, \mathrm{mAb} 225.28$ & [43] \\
\hline HER $2+$ & $17 \%$ & Unknown & Unknown & Data base & $\mathrm{IHC}, \mathrm{mAb} 225.28$ & {$[43]$} \\
\hline Lobular & $67 \%$ & Unknown & PFS & -- & $\mathrm{IHC}, \mathrm{mAb} 225.28 \mathrm{~S}$ & [65] \\
\hline Ductal & $3 \%$ & Unknown & Unknown & -- & $\mathrm{IHC}, \mathrm{mAb} 225.28 \mathrm{~S}$ & [65] \\
\hline $\mathrm{ER}^{+}, \mathrm{HER}^{+}{ }^{+}, \mathrm{PR}^{+}, \mathrm{TNBC}$ & $14.5-66.2 \%$ & $47.7 \%$ & TR (not TNBC), OS & -- & $\mathrm{IHC}, \mathrm{mAb} 83508$ & {$[72]$} \\
\hline \multicolumn{7}{|l|}{ Squamous cell carcinoma } \\
\hline Oral cavity & $100 \%$ & Unknown & Unknown & -- & $\mathrm{IHC}, \mathrm{mAb} 9.2 .27$ & {$[42]$} \\
\hline \multicolumn{7}{|l|}{ Pancreatic tumors } \\
\hline cystadenoma & $100 \%$ & -- & $\begin{array}{l}\text { diagnostic but not prognostic } \\
\text { relevance. }\end{array}$ & qPCR & $\begin{array}{l}\text { IHC,WB, Ab LHM2, } \\
\text { Ab H-300 }\end{array}$ & [167] \\
\hline $\begin{array}{l}\text { intraductal papillary mucinous } \\
\text { neoplasms }\end{array}$ & $100 \%$ & $100 \%$ & $\begin{array}{l}\text { diagnostic but not prognostic } \\
\text { relevance. }\end{array}$ & qPCR & $\begin{array}{l}\text { IHC,WB, Ab LHM2, } \\
\text { Ab H-300 }\end{array}$ & [167] \\
\hline Ductal malignancies & $100 \%$ & $100 \%$ & $\begin{array}{l}\text { diagnostic but not prognostic } \\
\text { relevance. }\end{array}$ & qPCR & $\begin{array}{l}\text { IHC,WB, Ab LHM2, } \\
\text { Ab H-300 }\end{array}$ & [167] \\
\hline \multicolumn{7}{|l|}{ Melanoma } \\
\hline Uveal & $69 \%$ & Unknown & Unknown & -- & $\mathrm{IHC}, \mathrm{mAb} 9.2 .27$ & [64] \\
\hline NS & $46-100 \%$ & $81-100 \%$ & Unknown & -- & $\begin{array}{l}\text { FACS, IHC, mAbs 225.28, 225.28S, } \\
\text { 149.53;763.74T, 763.74, VF1-TP41.2, } \\
\text { VT80.12 }\end{array}$ & $\begin{array}{l}{[8,56,65,} \\
67]\end{array}$ \\
\hline Acral lentiginous & $21-54 \%$ & $82 \%$ & OS, PFS & -- & $\begin{array}{l}\text { IHC, mAbs D2.8.5-C4B8, 225.28, TP41.2, } \\
\text { TP61.5 }\end{array}$ & $\begin{array}{l}{[58,60,} \\
68]\end{array}$ \\
\hline Nodular & $100 \%$ & $92 \%$ & Unknown & -- & IHC, mAbs 225.28, TP41.2, TP61.5 & {$[58]$} \\
\hline Superficial spreading & $100 \%$ & Unknown & Unknown & -- & $\mathrm{IHC}, \mathrm{mAb}$ D2.8.5-C4B8 & {$[68]$} \\
\hline Conjunctival & $100 \%$ & $100 \%$ & OS, MetP & -- & IHC, mAb LHM2 & [69] \\
\hline Desmoplastic & $95 \%$ & $87 \%$ & MetP & qPCR & $\begin{array}{l}\text { IHC, mAbs } \\
\text { 763.74, VF1-TP41.2, VT80.12 }\end{array}$ & {$[73]$} \\
\hline \multicolumn{7}{|l|}{ Mesothelioma } \\
\hline Sarcomatoid & $100 \%$ & Unknown & Unknown & -- & $\mathrm{IHC}, \mathrm{mAb}$ D2.8.5-C4B8 & {$[44]$} \\
\hline Epithelioid & $48 \%$ & Unknown & Unknown & -- & $\mathrm{IHC}, \mathrm{mAb}$ D2.8.5-C4B8 & {$[44]$} \\
\hline Biphasic & $100 \%$ & Unknown & Unknown & -- & $\mathrm{IHC}, \mathrm{mAb}$ D2.8.5-C4B8 & {$[44]$} \\
\hline \multicolumn{6}{|c|}{${ }^{1}$ Based upon studies reporting a minimum of 5 cases, including subvariants of the tumour; } & ${ }^{2}$ Frequency scoring, i.e. percentage of cases showing positivity out of the total analyzed; \\
\hline \multicolumn{7}{|c|}{${ }^{3}$ As determined by either gene expression profiling by DNA microarray or by real-time quantitative PCR (qPCR); } \\
\hline \multicolumn{7}{|c|}{${ }^{4} \mathrm{As}$ determined by immunohistochemistry (IHC) and/or Western blotting (WB; antibody clone code is indicated); } \\
\hline \multicolumn{7}{|c|}{ Includes pleomorphic and conventional leiomyosarcomas; } \\
\hline \multicolumn{7}{|c|}{${ }^{6}$ Includes myxoid, round-cell and pleomorphic liposarcoma variants; } \\
\hline \multicolumn{7}{|c|}{ 7From publicly accessible datasets (http://www.ncbi.nlm.nih.gov/geo/query/acc.cgi?acc=GSE5460); } \\
\hline
\end{tabular}





Figure 2. NG2/CSPG4 isoforms are strongly expressed in a variety of tumour types and are effectively exploitable for the identification of circulating cancer cells. (A-H) Examples of NG2/CSPG isoform distribution in selected tumour types known to frequently express high levels of the PG, as provided by immunostainings with propriety monoclonal antibodies and a Human Protein Atlas polyclonal antiserum: high grade cutaneous melanoma (A); ductal breast carcinoma (B, adapted and reprinted with permission from [71], courtesy Dr. M-F. Huo); adenocarcinoma of stomach (C); colorectal adenocarcinoma (D); chordoma (E; courtesy Dr. E. Tamborini); malignant glioblastoma (F, adapted and reprinted with permission from [112], courtesy Drs Francesco Girolamo and Daniela Virgintino); lung metastasis of synovial sarcoma $(\mathbf{G})$; and uterine leiomyosarcoma double stained with propriety monoclonal antibodies detecting cancer cell-associated versus pericyte-elective isoforms (H). (I) Detection of circulating cancer cells isolated from a patient with advanced melanoma through CD146-conjugated ferrofluid beads and enumerated and phenotyped by fluorescently labelled anti-CD34/CD45 and anti-NG2/CSPG4 antibodies (adapted and reprinted with permission from [86], courtesy Dr. L.W.M.M. Terstappen).

Given its documented diagnostic impact, it appears perplexing that NG2/CSPG4 has remained largely unutilized as a biomarker for the routine clinical monitoring of cancer patients. This may be due to the failure of most of the published studies to demonstrate the independence of dysregulated NG2/CSPG4 expression from established clinical parameters. One of the few exceptions may be our recent discovery in soft-tissue sarcomas; there, relative levels of expression of the PG in pulmonary metastatic lesions identifies a patient subgroup with an independently predicted adverse disease course (Table 1; $[24,45])$. As a clinically applicable adjunct, NG2/CSPG4 overexpression in primary lesions of soft-tissue sarcoma patients predicts the development of post-surgery metastases in these individuals within an average period of 12 months post-surgery and does so with the striking probability of about $65 \%$ [24]. In addition, there is evidence that enhanced NG2/CSPG4 expression in soft-tissue sarcoma and chordoma patients affects their response rate to combined radiation and chemotherapy, thereby stratify- ing responders versus non-responders and further underscoring the theranostic impact of the PG.

\section{Dismally fated leukemic patients de novo express NG2/CSPG4, down-stream of MLL rearrangements, to develop drug resistance}

Curiously, the strategy adopted for producing monoclonal antibodies against key cell surface antigens that originally led to the unfolding of NG2/CSPG4 in melanoma was reproduced on hematopoietic malignancies ten years later with same result: a unique antibody against NG2/CSPG4 was generated [94, 95]. The use of monoclonal antibody 7.1 obtained from this approach revealed the unexpected ectopic expression of NG2/CSPG4 on neoplastic cells from a subset (Table 2) of fate-compromised children suffering from acute myeloid leukemia (AML). By contrast, the PG was not found on normal T- and B-lymphocytes, monocytes, granulocytes, bone marrow hematopoietic stem/progenitor cells, platelets or red blood cells. The majority of AML patients (>75\%), whose neoplastic cells were found to express 
NG2/CSPG4, exhibited FAB-M4/M5 leukemic blasts carrying MLL gene rearrangements located on chromosome band 11q23. These cells exhibited a poorly differentiated $\left(\mathrm{CD}^{+}, \mathrm{CD} 7^{+}\right), \mathrm{CD}^{2} 6^{+}$myelomonocytic immunophenotype [94, 96-98], suggesting that NG2/CSPG4 expression strongly correlated with a stage maturation arrest.

Figure 3. Potential of NG2/CSPG4 as a prognostic biomarker. (A) Assessment of the relative NG2/CSPG4 transcript levels in primary versus pulmonary metastatic lesions (the two types of lesions derived from the same individual) in soft-tissue sarcoma patients $(n=86)$ affected by leiomyosarcoma, fibrosarcoma, liposarcoma, pleomorphic sarcoma or synovial sarcoma. A significantly ( $p<0.003$; univariate analysis) enhanced NG2/CSPG4 mRNA expression is detectable in metastatic formations (we have previously reported analogous data; [45, 52]). "Healthy tissue" corresponds to the surgical resection margins of the primary lesions. (B) Overall survival rates in soft-tissue sarcoma patients expressing higher $(n=65)$ or lower $(n=43)$ levels of NG2/CSPG4 mRNA in their lung metastases, following standard radiation and chemotherapy treatment and showing a significantly more favorable clinical course in patients with lower NG2/CSPG 4 mRNA levels ( $p<0.03$ by univariate analysis; Benassi, Pazzaglia and Perris, unpublished). (C) Overall survival rates of breast carcinoma patients expressing high levels of NG2/CSPG4, as determined by immunolabeling, when compared to patients with lower levels $(n=240)$. Even if more modestly, clinical outcome was significantly less dismal $(p=0.193$; univariate analysis) in patients with low NG2/CSPG4 levels (derived and adapted with permission from [71]; courtesy Dr. M.-F. Hou).

A series of subsequent studies concurred on the fact that $>60 \%$ of the leukemic cases with MLL rearrangements display NG2/CSPG4 cell surface expression, while, if reversed, high expression of the PG coincided in $80-100 \%$ of the cases with gene rearrangements (Table 2). Therefore, the consensus is that de novo expression of NG2/CSPG4 tightly correlates with 11q23-associated genetic abnormalities and identifies a specific and well-defined subset of leukemic patients with a putative unfavourable prognosis. Pioneering investigations on infants affected by acute lymphoblastic leukemia (ALL) similarly identified subgroups of patients whose leukemic cells de novo expressed NG2/CSPG4 in association with $\mathrm{t}(11 ; 19)(\mathrm{q} 23 ; \mathrm{p} 13), \mathrm{t}(4 ; 11)(\mathrm{q} 21 ; \mathrm{q} 23)$ and $\mathrm{t}(9 ; 11)(\mathrm{q} 21 ; \mathrm{q} 23)$ translocations [95, 98, 99]. These original findings were tightly corroborated by computational, quantitative and quantitative flow cytometry analyses performed on 1,461 infants with B-ALL. Thanks to these investigations,although NG2/CSPG4 expression was restricted to a subgroup of patients presenting MLL rearrangements, we can theoretically suppose that all patients with NG2/CSPG4-positive leukemic blasts could have coincident MLL rearrangements [100], i.e. NG2/CSPG4 expression was asserted to be "diagnostic" of MLL gene aberrations. Furthermore, the linkage between induced NG2/CSPG4 expression and MLL gene alterations is not limited to childhood leukemia, but is also seen in adult ALL patients. In this case, the NG2/CSPG4-expressing phenotype is a typical precursor B-cell, displaying the CD10-/CD13-/CD15 $/$ CD22 + /CD24-/CD33-/CD65s ${ }^{+}$
A



B


/CD117 phenotype, a variable expression of CD19 and CD34, and absence of leukemic stem cell traits [98, 101-103].

Collectively, the above investigations on acute leukemia affirm a stringent correlation between MLL rearrangements, rare variants with often peculiar cell phenotypes [104], and ectopic expression of NG2/CSPG4. However, they leave veiled several biological and clinical questions, including the biological significance of the NG2/CSPG4 expression on discrete leukemic cells and the therapeutic potential of this selective expression. The negative outcome of the experimental targeting of a model leukemic cell line with two anti-NG2/CSPG4 antibodies [105], independently validated as effective tools for abrogat- 
ing growth and dissemination of solid tumour xenografts (see below), reinforces these uncertainties. In parallel, in a recent publication Petrovici et al. [106], reported some AML cases manifesting a normal karyotype, while, concurrently, a significant amount of the leukemic cells expressed NG2/CSPG4. This finding together with the frequency of NG2/CSPG4 expression on plasmacytoid dendritic leukemia cell lines lacking MLL abnormalities and having the immunophenotype $\mathrm{CD} 4^{+} / \mathrm{CD}_{3} 8^{+} / \mathrm{CD} 45^{+} / \mathrm{CD} 123^{+} / \mathrm{HLADR}^{+}$ [107] have led investigators to draw an important conclusion: in the absence of MLL rearrangements, expression of the PG on leukemic cells may be dictated by the context within which leukemogenesis is initiated [108]. Since no other onco-hematological disease has presently been disclosed to involve misexpression of NG2/CSPG4, the unprecedented surface display in hematopoietic cells (else than macrophages and brain microglia) appears to be a facultative leukemogenesis-specific event.

Additional unresolved issues of the leukemia-NG2/CSPG4 linkage are: whether ectopic/enhanced expression of the PG electively correlates with a specific MLL rearrangement? Whether transcription/translation of the PG is a direct consequence of such genetic anomaly? Currently published data do not support a specific link between NG2/CSPG4 surface expression and a specific MLL rearrangement, while many works support the conjecture that such gene rearrangements may trigger the ectopic surface appearance of the PG. In fact, we have recently found that transduction of the MF4 fusion product into leukemic cells, not harboring this genetic aberration, activates NG2/CSPG4 gene transcription and surface display of the PG [unpublished]. We also find that induced NG2/CSPG4 expression in leukemic MLL re- arranged cells confer to them a generalized drug resistance manifested by up-regulation of several drug transporters [unpublished]. Thus, enhanced NG2/CSPG4 expression in leukemic cells may promote their aggressiveness in a cell-autonomous manner and thereby contribute to the dismal clinical course of these patients.

\section{NG2/CSPG4 may pair with cancer initiat- ing cell subsets}

Despite its reportedly unfavourable prognostic connotation, the presence of NG2/CSPG4 on AML cells having a CD34-/CD38 ${ }^{+}$phenotype is claimed to be incompatible with an elective expression of the PG on candidate leukemic stem cells [i.e. the PG may either be present or not on such cells; [102]. However, this claim is based upon examination of only 6 leukemic cases, calling upon more in depth analyses to firmly establish the identity of the NG2/CSPG4-presenting leukemic cells. In cerebral and oral cavity tumours, experimental evidence also would seem to confute a strict correspondence between putative stem cells and highly malignant NG2/CSPG4-expressing cells ([69, 109-111]; Rossi et al., submitted). However, in gliomas [69, 110, 112], soft-tissue sarcomas [24], oral cavity carcinomas (Rossi et al., submitted), breast carcinoma [42] and mesothelioma [43] NG2/CSPG4 is found on average on $<50 \%$ of the cells composing the tumour lesion and, in most cases, these cells seem to harbor tumour initiating properties. Accordingly, immunotargeting of CD20-NG2/CSPG4-expressing melanoma cell subsets in animal models eradicates the predominant portion of the tumour [113].

Table 2. Diagnostic-prognostic implications of NG2/CSPG4 expression in hematological malignancies ${ }^{1}$

\begin{tabular}{|c|c|c|c|c|c|c|c|}
\hline Leukemia & Age group & $\begin{array}{l}\text { NG2/CSPG4 } \\
\text { positive cases }{ }^{2} \\
\text { (out of } n \text { ) }\end{array}$ & $\begin{array}{l}\text { NG2/CSPG4 positivity vs preva- } \\
\text { lent FAB status/Phenotype } \\
\text { of MLL rearranged cases }\end{array}$ & $\begin{array}{l}\text { NG2/CSPG4 positivity } \\
\text { in MLL germline cases } \\
\text { (out of } n \text { ) }\end{array}$ & $\begin{array}{l}\text { NG2/CSPG4 positivity in } \\
\text { MLL rearranged cases } \\
\text { (out of } n \text { ) }\end{array}$ & $\begin{array}{l}\text { Disease } \\
\text { course }\end{array}$ & References \\
\hline$\overline{\text { ALL }}$ & Infant & $9 \%(104)$ & $56 \%$ pro-B; $33 \%$ pre-B; $11 \%$ T-ALL & $0 \%(89)$ & $100 \%(9)$ & ND & [96] \\
\hline AML & Infant & $11 \%(166)$ & $67 \%$ M5 & $0 \%(85)$ & $78 \%(18)$ & Poor & [95] \\
\hline AML & Infant & $35 \%(37)$ & $58 \% \mathrm{M} 4 / \mathrm{M} 5$ & $0 \%(13)$ & $54 \%(24)$ & Unaffected & [97] \\
\hline AML & Infant/Adult & $43 \%(14)$ & $75 \%$ M5 & $0 \%(25)$ & $43 \%(14)$ & ND & [98] \\
\hline $\begin{array}{l}\text { AML/ } \\
\text { ALL }\end{array}$ & Infant/Adult & $14 \%(533)$ & $\begin{array}{l}\text { NS } \\
25 \% \text { myeloid/NK cell ALL; } 16 \% \\
\text { pro-/pre-B- ALL }\end{array}$ & $2 \%(12)$ & $81 \%(72)$ & ND & [99] \\
\hline ALL & Adult & $23 \%(313)$ & 78 pro-B, $11 \%$ pre-B & $19 \%(48)$ & $89 \%(72)$ & ND & [102] \\
\hline $\begin{array}{l}\text { AML/ } \\
\text { ALL }\end{array}$ & Infant & $82 \%(11)$ & NS & ND & $100 \%(9)$ & Poor & [103] \\
\hline ALL & Adult & $95 \%(184)$ & $100 \%$ pro-/pre-B & $15 \%(66)$ & $91 \%(118)$ & ND & [104] \\
\hline AML & Adult & $23 \%(70)$ & $50 \%$ M5 & $29 \%(62)$ & $63 \%(8)$ & Poor & [107] \\
\hline $\begin{array}{l}\text { AML/ } \\
\text { ALL }\end{array}$ & Infant & $48 \%(311)$ & $\begin{array}{l}\text { NS } \\
90 \% \text { pro-B, } 6 \% \text { T-ALL }\end{array}$ & $58 \%(143)$ & $42 \%(143)$ & ND & [100] \\
\hline
\end{tabular}

${ }^{1}$ As established by flow cytometry using the reference $\mathrm{mAb} 7.1$.

${ }^{2}$ Adopted average cut-off was $>25 \%$ of leukemic blasts;

${ }^{3} \mathrm{NG} 2 / \mathrm{CSPG} 4$ expression has also been documented in one case of DC2/NK cell ALL [105];

Abbreviations: $\mathrm{NS}=$ not specified; $\mathrm{ND}=$ not determined. 
Heterogeneity of intra-lesional NG2/CSPG4 expression hence corroborates the idea that the PG pertains to aggressive cancer cell subsets, albeit no correlation studies have yet been published to clarify whether the average number of NG2/CSPG4 positive cells within a primary or secondary tumour lesion discriminates patient subgroups with a diverse clinical course. Nevertheless, the exacerbated malignant properties of NG2/CSPG4-expressing cancer cell populations $([3,24,94,110]$; Nicolosi et al., in preparation) co-expressing markers of immature cell types strongly favors the notion that, at least in solid tumours, NG2/CSPG4 may be associated with cancer stem/cancer initiating cells [42]. In addition, we have recently observed that subpopulations of glioblatoma cells display NG2/CSPG4 variants immunologically distinct from those found on normal and tumorigenic perivascular cells and developing glial cell progenitors [112]. This finding highlights a remarkable structural variability of NG2/CSPG4 in cerebral cancers and points to the potential of targeting selective neoplastic cells of these tumours, which may correspond to cancer initiating cells, with isoform-specific antibodies.

\section{Insights into the putative function of NG2/CSPG4 in cancer inception and pro- gression gained from tumorigenesis studies in animal models}

More than 40 different cancer cell lines constitutively expressing high levels of NG2/CSPG4, or transduced to ectopically express the PG, display enhanced aggressiveness in syngenic or xenogenic transplantation settings. Moreover, we have recently shown that the magnitude of local growth of xenografted sarcoma cells is largely proportional to the relative levels of NG2/CSPG4 on their surfaces ([24]; Nicolosi et al., in preparation). Hence, these and numerous other investigations corroborate a widespread tumour-promoting activity of NG2/CSPG in solid tumours, which is exhibited by promotion of four cancer-related cellular phenomena: (I) survival in stressed conditions, (II) drug resistance, (III) intra-lesional neovascularisation, and (IV) metastatic ability (Fig. 1). Supportive findings from in vitro assays purport the concept that NG2/CSPG4 may affect drug sensitivity of cancer cells by reinforcing their interactions with the host microenvironment, especially with the stromal ECM, by modulating the activity of certain integrins and, through these actions, by activating pro-survival signalling cascades [22, 24, 114-116]. Conversely, NG2/CSPG4 does not seem to interfere with apoptosis or autophagy. It has been argued that the ability of NG2/CSPG4 to elicit signal- ling cascades involving the PI-3K-Akt-1-mTOR axis, possibly through an upstream activation of ERK and PKC-related pathways ([3, 18, 19, 22-24]; Cattaruzza et al., unpublished), is the key pro-survival mechanism operated by the PG. Phosphorylation of the cytoplasmic threonines of NG2/CSPG4 is likely to be an obligatory step for the co-activation of these cell survival-associated signalling events resulting from associations of the PG with the ECM [19, 24]. Recent indirect evidence for a significant role of NG2/CSPG4 in controlling responses to target therapy drugs stems from the ability of anti-NG2/CSPG4 antibodies to prolong the growth inhibitory effect of the BRAFV600E inhibitor vemurafenib [117].

Exploitation of the NG2/CSPG4 knockout mouse alone, or in combination with PDGFR $\beta$ null mice, highlights another facet of the NG2/CSPG4 involvement in tumour progression. In a NG2/CSPG4-poor background, tumour growth and spreading is strongly impaired indicating that the PG is an essential component of the tumour microenvironment. Experimental evidence substantiating a tight association between the host PG and the formation of intra-lesional neovessels (Fig. 3) provides one conceivable explanation for how NG2/CSPG4 of the tumour microenvironment may influence cancer growth. The role of the PG in angiogenesis is bimodal as it involves a direct control of the behaviour of sprouting neovascular cells $[62,118-120]$ and the coincident sequestration of angiocrine factors $[1,51,52$, 121]. This latter event may in turn promote multivalent molecular interactions favouring the intimate interplays between pericytes, the endothelium and the tumour cells $[112,116,120,122,123]$. Accordingly, simulation of the neovascularisation process in vitro, growth factor-induced angiogenesis in the corneal experimental paradigm [52, 124], and subcutaneous cell-matrix transplantation approaches (e.g. so called "Matrigel plug" assays), consistently support the pivotal pericyte-linked function of NG2/CSPG4. Some of these experimental systems have additionally unveiled an unprecedented implication of the PG in the recruitment of tumour-infiltrating macrophages [125], while bringing to the attention the precocious contribution of resident and bone marrow-derived NG2/CSPG4-expressing pericytes to the angiogenic sprouting process [125-129].

Induced expression of NG2/CSPG4 in cells lacking the PG may accentuate their metastatic potential $[43,91,130]$ and, accordantly, knockdown via RNAi of the endogenous PG represses local growth in primary tumour grafting models [69, 70]. These observations let hypothesize that a wealth of NG2/CSPG4 immunotargeting approaches forcefully could implicate the PG in cancer progression (Table 
3). Averted growth and dissemination of xenografted cancer cells has been documented in animals receiving anti-NG2/CSPG4 antibodies, when such have been employed in their naked canonical form, in their mono- and bivalent recombinant versions, or as conjugates with a variety of cytotoxic and/or pro-apoptotic agents. While the overwhelming majority of these studies have traditionally focused on melanoma [70, 91, 113, 119, 131-144], a number of other tumour types, such as mesothelioma [43], head neck squamous cell carcinoma [144], glioblastoma [22, $48,69,70,120,145-147]$ and breast carcinoma [42, 123, $141,144]$ have recently emerged as equally targetable (Table 3). In most instances of NG2/CSPG4 targeting through naked antibodies, the tumour-abrogation effect caused by the antibody treatments has been attributed to a decrease of FAK and ERK(-pathway) activation. However, since the cross-reactivity of these antibodies with the host murine NG2/CSPG4

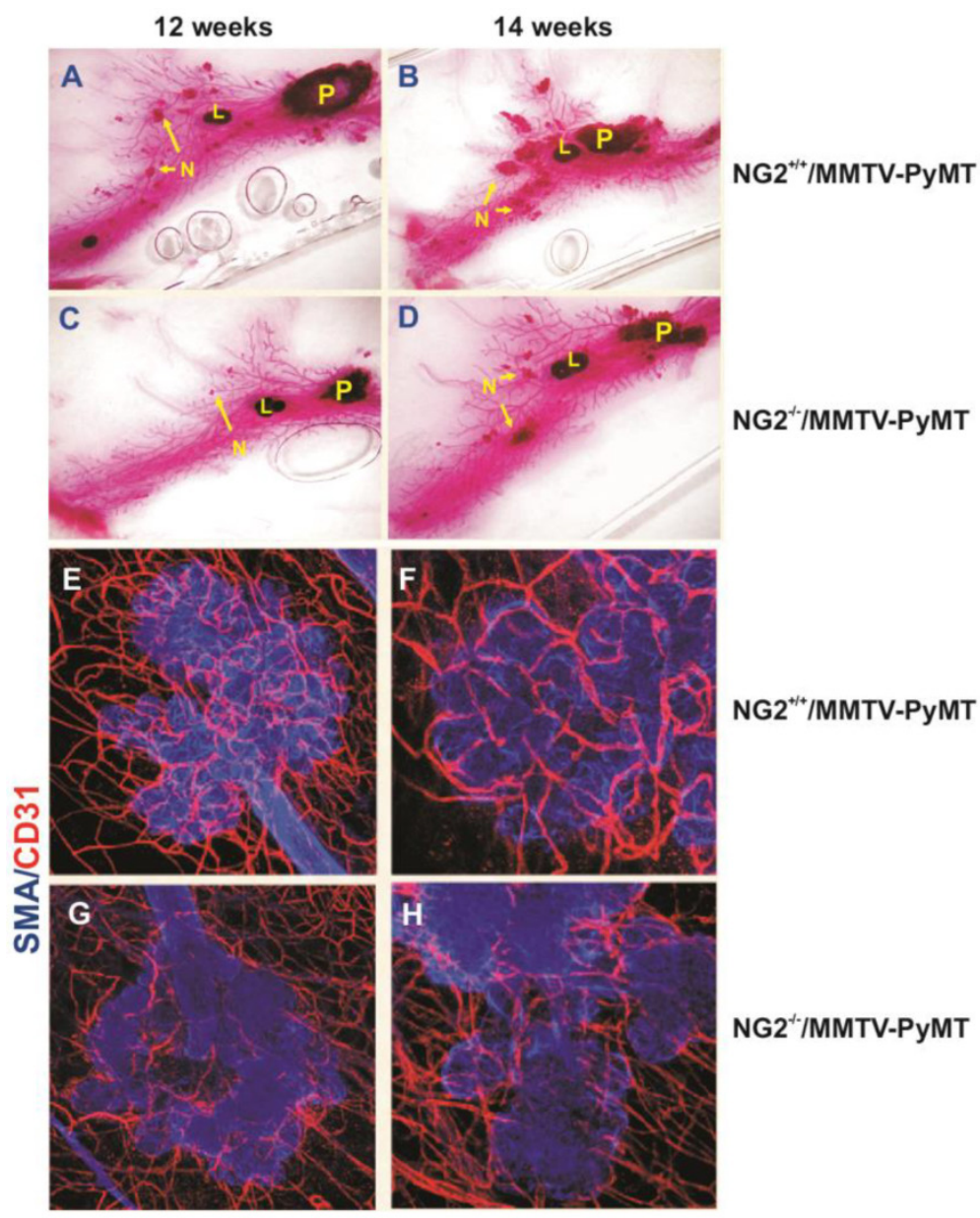

Figure 4. Implication of NG2/CSPG4 in tumour angiogenesis, as evidence in a virally induced mouse model of mammary carcinoma (MMTV-PyMT; derived and adapted with permission from [123], courtesy Dr. W.B. Stallcup) . (A-D) Primary $(P)$ and secondary $(N)$ lesions (including lymphnodal infiltration; "L") induced in wild type (A, B) and NG2/CSPG4 null mice (C, D), as shown by Carmine alum staining of mammary glands in the two genotypes. (E-H) Extension of the neovascular network developed in carcinoma lesions arising in wild type (E, $\mathbf{F})$ and NG2/CSPG4 null $(\mathbf{G}, \mathbf{H})$ mice (endothelial and pericyte markers, CD31 and $\alpha \mathrm{SMA}$, respectively). orthologue was not determined and the precise basis for the reduced phosphorylations has not convincingly been addressed, it is uncertain whether dephosphorylation of the above signalling components was directly attributed to the antibody-cancer antigen reaction. Thus, although these findings solidly demonstrate the applicability of NG2/CSPG4 as an immunotherapeutic target, they leave veiled the modalities through which such a therapeutic approach should be coaxed to bring about an effective tumour eradication.

Direct immunotargeting of NG2/CSPG4 may latently arrest growth and dissemination of a variety of cancer cell types in different experimental settings, but a number of more indirect targeting approaches have also proven to generate the desired tumour-abrogating results (Table 3). Chimeric anti-NG2/CSPG4 antibodies fused to superantigens [134], or to apoptosis-inducing receptor ligands (such as TRAIL; [138], and bi- [148] or tri-specific [149] antibodies simultaneously targeting ancillary antigens) effectively reduce tumour burden in mice. More recently, bispecific antibodies constructed such as to bind both NG2/CSPG4 and the lymphocyte receptor $\mathrm{CD} 3$ and allowing redirection of the cytotoxic activity of T lymphocytes toward melanoma cells [so called "BiTi technology"; [66, 150, 151] have been exploited to engender NG2/CSPG4-mediated immune attack of cancer cells. These investigations and other studies reinforce the innate NG2/CSPG4 immunodominant properties, manifested by the CTL-4 responses that the PG seems to evoke against the tumour cells and the induction of auto-antibodies against specific epitopes of NG2/CSPG4 in the absence of a generalized autoimmunity [152-155]. Anti-tumour (primarily melanoma) immunereactions may also be elicited by NG2/CSPG4 mimotopes [137, 156, 157], suggesting that the PG encompasses strongly (auto-)immunogenic sequences capable of priming dendritic and/or immune cells upon their pathological activation (i.e. in the context of inflammatory conditions as those ruling in cancer patients). However, mimotopes found to be capable of inducing anti-NG2/CSPG4 immune responses do not match with the N-terminal peptide found to be recognized by $\mathrm{CD}^{+} \mathrm{T}$ cells in both healthy individuals and melanoma patients and presumed to correspond to a self-tolerant sequence of the PG $[154,155]$. 
${ }^{7} \mathrm{Lm}$-LLO-HMW-MAA-C = Recombinant Lm(Listeria monocytogenes)-based vaccine secreting a fragment of NG2/CSPG4 fused to LLO;

${ }^{8}$ Intra-uterus injection of PDGF-BB or NG2/CSPG4-directed miRNA into E14 embryonic brains;

9NG2/CSPG4 floxed mice and PDGFR-B-Cre transgenic mice were backcrossed to a C57Bl/ 6 background;

${ }^{10} \mathrm{TH} 10-\mathrm{DTX}-\mathrm{NP}=\mathrm{TH} 10$ peptide $(\mathrm{TAASGVRSMH})$ conjugated to docetaxel-loaded nanoparticles.

\section{How far are we from the adoption of NG2/CSPG4 as a clinically accepted thera- peutic target?}

Despite the lack of broader mechanistic insights, the success rate of anti-NG2/CSPG4 immunological agents affords a solid pre-clinical rationale for attempting the eradication of different tumour types through NG2/CSPG4 targeting. However, an obvious caveat with these pre-clinical studies is that they have been performed in xenogenic settings with putative human NG2/CSPG4-specific antibodies. This leaves uncertain the possible side effects that these immunological agents may have on healthy cells, especially on the numerous PG-expressing progenitor cells (including perivascular ones), and the extent to which these agents may affect homeostatic phenomena such as wound healing and tissue regeneration. On the other hand, a concurrent NG2/CSPG4-directed attack of malignant cancer cells and the pericyte subsets driving tumour angiogenesis is generally believed to be an attractive double-targeting approach. If striving at using NG2/CSPG4 as a preferred target for tumour abrogation, one way of circumventing disturbing collateral effects may be the elective targeting of cell type-specific glycoforms of the PG ([112]; Dallatomasina et al., in preparation). In addition, we have observed an extensive nucleotide and amino acid polymorphism of NG2/CSPG4 in tumour cell lines and in circulating cancer cells of soft-tissue sarcoma patients (Dallatomasina et al., in preparation). Collectively, these recent findings highlight the potential to utilize anti-NG2/CSPG4 immunological reagents with finer antigen specificity than those previously exploited such as to target discrete and well-defined cancer cell subsets.

Off-target effects that might incidentally be encountered when attempting a direct pan-immunetargeting of NG2/CSPG4, may analogously be obtained when exploring active immunotherapeutic approaches based upon immunization of patients with anti-idiotypic antibodies [158-161]. Nevertheless, documented clinical benefits of NG2/CSPG4 anti-idiotypic antibody treatment of cancer patients has led to the ranking of the PG within the 100 most effective tumour markers for vaccination approaches on cancer patients [162]. Effectiveness of NG2/CSPG4directed immunization strategies were originally suggested by clinical studies entailing vaccination of advanced melanoma patients with the anti-idiotypic antibody MK2-23, which mimics a 15 amino acid se- quence within the NG2/CSPG4 recognized by antibody 763.74 [163]. Treatment of more than 80 patients with mAb MK2-23, alone or when conjugated to immunogenicity enhancers, was found to reduce the sizes of metastatic lesions and to significantly prolong patient survival, presumably by eliciting a multitude of humoral immunological responses that could span from $T$ cell-mediated production of anti-anti-idiotypic antibodies to the endogenous production of antibodies directed against NG2/CSPG4 [164-166]. Regression analyses consistently demonstrated that induction of antibodies against NG2/CSPG4 were the primary correlate with extended patient survival and strongly suggested that re-evoked and/or augmented levels of anti-NG2/CSPG4 auto-antibodies were the bases for the observed curing effects.

The approximately $50 \%$ success rate observed in these inceptive clinical studies has incited a more extended Phase II trial performed at CRO National Cancer Institute Aviano (Italy) on over 100 advanced melanoma patients who were selected for the high NG2/CSPG4 expression in the primary lesions and lack of brain metastases. These individuals were subjected to prolonged vaccination regimens with $\mathrm{mAb}$ MK2-23, alone or in combination with adjuvant IL-2 or GMS-F administration. The striking outcome of this study was that, when evaluated within a follow-up period of more than 10 years, an unexpected $12 \%$ of patients manifested complete disease remission and about another $20 \%$ experienced a stall of the disease (M. Maio, personal communication). Again, the observed clinically tangible effects markedly correlated with high serum levels of anti-NG2/CSPG4 antibodies and alloreactive T lymphocytes. Passive and active NG2/CSPG4 immunotargeting approaches are therefore believed to harbor the potential to intervene in the progression of the numerous tumour types discovered to overexpress the PG. These approaches may effectively be paralleled by approaches relying upon antibody dependent cytotoxicity in which isoform-specific anti-NG2/CSPG4 antibodies may be employed to ameliorate the targeting specificity.

\section{Acknowledgements}

The authors wish to thank Drs Leon W.M.M. Terstappen, MIRA Research Institute for Biomedical Technology and Technical Medicine, University of Twente, The Netherlands; William B Stallcup, the Sandorf-Burnham Research Institute for Medicine, LaJolla, USA; Francesco Girolamo and Daniela Virgintino, University of Bari, Italy; Elena Tamborini, the 
National Cancer Institute, Milan, Italy; and Ming-Feng Huo, Kaohsiung Medical University, Taiwan, for providing documentation of published and unpublished data. We also acknowledge the valuable financial support from AIRC (Associazione Italiana per la Ricerca sul Cancro), Grant Call 2009, from the Italian Ministry of Health, RF2009, by institutional funds, from the EU-funded project POR-FESR "Creazione di Tecnopoli" and by fellowships provided by Associazione Casa via di Natale, Pordenone, Italy. Drs. Domenica Mangieri and Mirca Lazzaretti are thanked for performing some of the IHC and for the assistance with the preparation of the artwork.

\section{Competing Interests}

The authors have declared that no competing interest exists.

\section{References}

1. Chekenya M, Hjelstuen M, Enger P O, et al. NG2 proteoglycan promotes angiogenesis-dependent tumor growth in CNS by sequestering angiostatin. FASEB J. 2002;16:586-588

2. Stallcup $\mathrm{W} \mathrm{B}$ and Huang F J. A role for the NG2 proteoglycan in glioma progression. Cell Adh Migr. 2008;2:192-201

3. Yang J, Price M A, Li G Y, et al. Melanoma proteoglycan modifies gene expression to stimulate tumor cell motility, growth, and epithelial-to-mesenchymal transition. Cancer Res. 2009;69:7538-7547

4. Campoli M R, Chang C C, Kageshita T, Wang X, McCarthy J B and Ferrone S. Human high molecular weight-melanoma-associated antigen (HMW-MAA): a melanoma cell surface chondroitin sulfate proteoglycan (MSCP) with biological and clinical significance. Crit Rev Immunol. 2004;24:267-296

5. Garusi E, Rossi S and Perris R. Antithetic roles of proteoglycans in cancer. Cell Mol Life Sci. 2012;69:553-579

6. Wilson B S, Ruberto G and Ferrone S. Immunochemical characterization of a human high molecular weight--melanoma associated antigen identified with monoclonal antibodies. Cancer Immunol Immunother. 1983;14:196-201

7. Natali P G, Segatto O, Zupi G, Cavaliere R, Giacomini P and Ferrone S. Isolation of viable melanoma cells from surgically removed lesions using dishes coated with monoclonal antibody to a high molecular weight melanoma associated antigen. J Immunol Methods. 1983;62:337-346

8. Natali P G, Viora M, Nicotra M R, Giacomini P, Bigotti A and Ferrone S. Antigenic heterogeneity of skin tumors of nonmelanocyte origin: analysis with monoclonal antibodies to tumor-associated antigens and to histocompatibility antigens. J Natl Cancer Inst. 1983;71:439-447

9. Natali P G, Bigotti A, Cavaliere R, Nicotra M R and Ferrone S. Phenotyping of lesions of melanocyte origin with monoclonal antibodies to melanoma-associated antigens and to HLA antigens. J Natl Cancer Inst. 1984:73:13-24

10. Giacomini P, Ng A K, Kantor R R, Natali P G and Ferrone S. Double determinant immunoassay to measure a human high-molecular-weight melanoma-associated antigen. Cancer Res. 1983;43:3586-3590

11. Giacomini P, Veglia F, Cordiali Fei P, Rehle T, Natali P G and Ferrone S. Level of a membrane-bound high-molecular-weight melanoma-associated antigen and a cytoplasmic melanoma-associated antigen in surgically removed tissues and in sera from patients with melanoma. Cancer Res. 1984;44:1281-1287

12. Stallcup W B. . The NG2 antigen, a putative lineage marker: immunofluorescent localization in primary cultures of rat brain. Dev Biol. 1981;83:154-165

13. Nishiyama A, Dahlin K J, Prince J T, Johnstone S R and Stallcup W B. The primary structure of NG2, a novel membrane-spanning proteoglycan. J Cell Biol. 1991;114:359-371

14. Pluschke G, Vanek M, Evans A, et al. Molecular cloning of a human melanoma-associated chondroitin sulfate proteoglycan. Proc Natl Acad Sci USA. 1996;93:9710-9715

15. Rettig W J, Real F X, Spengler B A, Biedler J L and Old L J. Human melanoma proteoglycan: expression in hybrids controlled by intrinsic and extrinsic signals. Science. 1986;231:1281-1284

16. Nishiyama A, Lin X H and Stallcup W B. Generation of truncated forms of the NG2 proteoglycan by cell surface proteolysis. Mol Biol Cell. 1995;6:1819-1832

17. Asher R A, Morgenstern D A, Properzi F, Nishiyama A, Levine J M and Fawcett J W. Two separate metalloproteinase activities are responsible for the shedding and processing of the NG2 proteoglycan in vitro. Mol Cell Neurosci. 2005;29:82-96

18. Makagiansar I T, Williams S, Dahlin-Huppe K, Fukushi J, Mustelin T and Stallcup W B. Phosphorylation of NG2 proteoglycan by protein kinase C-alpha regulates polarized membrane distribution and cell motility. J Biol Chem. 2004;279:55262-55270
19. Makagiansar I T, Williams S, Mustelin T and Stallcup W B. Differential phosphorylation of NG2 proteoglycan by ERK and PKCalpha helps balance cell proliferation and migration. J Cell Biol. 2007;178:155-165

20. Eisenmann K M, McCarthy J B, Simpson M A, et al. Melanoma chondroitin sulphate proteoglycan regulates cell spreading through Cdc42, Ack-1 and p130cas. Nat Cell Biol. 1999;1:507-513

21. Majumdar M, Vuori K and Stallcup W B. Engagement of the NG2 proteoglycan triggers cell spreading via rac and p130cas. Cell Signal. 2003;15:79-84

22. Chekenya M, Krakstad C, Svendsen A, et al. The progenitor cell marker NG2/MPG promotes chemoresistance by activation of integrin-dependent PI3K/Akt signaling. Oncogene. 2008;27:5182-5194

23. Joo N E, Watanabe T, Chen C, Chekenya M, Stallcup W B and Kapila Y L. NG2, a novel proapoptotic receptor, opposes integrin alpha4 to mediate anoikis through PKCalpha-dependent suppression of FAK phosphorylation. Cell Death Differ. 2008;15:899-907

24. Cattaruzza S, Nicolosi P A, Braghetta P, et al. NG2/CSPG4-collagen type VI interplays putatively involved in the microenvironmental control of tumour engraftment and local expansion. J Mol Cell Biol. 2013;5:176-193

25. Natali P, Bigotti A, Cavalieri R, Wakabayaski S, Taniguchi M and Ferrone S. Distribution of a cross-species melanoma-associated antigen in normal and neoplastic human tissues. J.Invest.Dermatol. 1985;85:340-346

26. Nishiyama A, Dahlin K J and Stallcup W B. The expression of NG2 proteoglycan in the developing rat limb. Development. 1991;111:933-944

27. Levine J M and Nishiyama A. The NG2 chondroitin sulfate proteoglycan: a multifunctional proteoglycan associated with immature cells. Perspect Dev Neurobiol. 1996;3:245-259

28. Midwood K S and Salter D M. Expression of NG2/human melanoma proteoglycan in human adult articular chondrocytes. Osteoarthritis Cartilage. 1998;6:297-305

29. Grako K A, Ochiya T, Barritt D, Nishiyama A and Stallcup W B. PDGF (alpha)-receptor is unresponsive to PDGF-AA in aortic smooth muscle cells from the NG2 knockout mouse. J Cell Sci. 1999;112 ( Pt 6):905-915

30. Petrini S, Tessa A, Carrozzo R, et al. Human melanoma/NG2 chondroitin sulfate proteoglycan is expressed in the sarcolemma of postnatal human skeletal myofibers. Abnormal expression in merosin-negative and Duchenne muscular dystrophies. Mol Cell Neurosci. 2003;23:219-231

31. Petrini S, Tessa A, Stallcup W B, et al. Altered expression of the MCSP/NG2 chondroitin sulfate proteoglycan in collagen VI deficiency. Mol Cell Neurosci. 2005;30:408-417

32. Legg J, Jensen U B, Broad S, Leigh I and Watt F M. Role of melanoma chondroitin sulphate proteoglycan in patterning stem cells in human interfollicular epidermis. Development. 2003;130:6049-6063

33. Ghali L, Wong S T, Tidman N, Quinn A, Philpott M P and Leigh I M. Epidermal and hair follicle progenitor cells express melanoma-associated chondroitin sulfate proteoglycan core protein. J Invest Dermatol. 2004;122:433-442

34. Dellavalle A, Sampaolesi M, Tonlorenzi R, et al. Pericytes of human skeletal muscle are myogenic precursors distinct from satellite cells. Nat Cell Biol. 2007;9:255-267

35. Kozanoglu I, Boga C, Ozdogu H, et al. Human bone marrow mesenchymal cells express NG2: possible increase in discriminative ability of flow cytometry during mesenchymal stromal cell identification. Cytotherapy. 2009;11:527-533

36. Giangreco A, Goldie S J, Failla V, Saintigny G and Watt F M. Human skin aging is associated with reduced expression of the stem cell markers beta1 integrin and MCSP. J Invest Dermatol. 2010;130:604-608

37. Ugarte G, Cappellari O, Perani L, Pistocchi A and Cossu G. Noggin recruits mesoderm progenitors from the dorsal aorta to a skeletal myogenic fate. Dev Biol. 2012;365:91-100

38. Navone S E, Marfia G, Canzi L, et al. Expression of neural and neurotrophic markers in nucleus pulposus cells isolated from degenerated intervertebral disc. J Orthop Res. 2012;30:1470-1477

39. Russell K C, Tucker H A, Bunnell B A, et al. Cell-surface expression of neuron-glial antigen 2 (NG2) and melanoma cell adhesion molecule (CD146) in heterogeneous cultures of marrow-derived mesenchymal stem cells. Tissue Eng Part A. 2013;19:2253-2266

40. Wiest T, Hyrenbach S, Bambul P, et al. Genetic analysis of familial connective tissue alterations associated with cervical artery dissections suggests locus heterogeneity. Stroke. 2006;37:1697-1702

41. Jensen K B, Jones J and Watt F M. A stem cell gene expression profile of human squamous cell carcinomas. Cancer Lett. 2008;272:23-31

42. Wang X, Osada T, Wang Y, et al. CSPG4 protein as a new target for the antibody-based immunotherapy of triple-negative breast cancer. J Natl Cancer Inst. 2010;102:1496-1512

43. Rivera Z, Ferrone S, Wang X, et al. CSPG4 as a target of antibody-based immunotherapy for malignant mesothelioma. Clin Cancer Res. 2012;18:5352-5363

44. Gazziola C, Cordani N, Wasserman B, Carta S, Colombatti A and Perris R. Malignant fibrous histiocytoma: a proposed cellular origin and identification of its characterizing gene transcripts. Int J Oncol. 2003;23:343-351

45. Benassi M S, Pazzaglia L, Chiechi A, et al. NG2 expression predicts the metastasis formation in soft-tissue sarcoma patients. J Orthop Res. 2009;27:135-140

46. Johansson F K, Brodd J, Eklof C, et al. Identification of candidate cancer-causing genes in mouse brain tumors by retroviral tagging. Proc Natl Acad Sci USA. 2004;101:11334-11337

47. Jiang Y, Boije M, Westermark B and Uhrbom L. PDGF-B Can sustain self-renewal and tumorigenicity of experimental glioma-derived can- 
cer-initiating cells by preventing oligodendrocyte differentiation. Neoplasia. 2011;13:492-503

48. Terrile M, Appolloni I, Calzolari F, Perris R, Tutucci E and Malatesta P. PDGF-B-driven gliomagenesis can occur in the absence of the proteoglycan NG2. BMC Cancer. 2010;10:550-2407-10-550

49. Grako K A and Stallcup W B. Participation of the NG2 proteoglycan in rat aortic smooth muscle cell responses to platelet-derived growth factor. Exp Cell Res. 1995;221:231-240

50. Nishiyama A, Lin X H, Giese N, Heldin C H and Stallcup W B. Interaction between NG2 proteoglycan and PDGF alpha-receptor on O2A progenitor cells is required for optimal response to PDGF. J Neurosci Res. 1996:43:315-330

51. Goretzki L, Burg M A, Grako K A and Stallcup W B. High-affinity binding of basic fibroblast growth factor and platelet-derived growth factor-AA to the core protein of the NG2 proteoglycan. J Biol Chem. 1999;274:16831-16837

52. Cattaruzza S, Ozerdem U, Denzel M, et al. Multivalent proteoglycan modulation of FGF mitogenic responses in perivascular cells. Angiogenesis. 2013;16:309-327

53. Dyson S and Gurdon J B. The interpretation of position in a morphogen gradient as revealed by occupancy of activin receptors. Cell. 1998;93:557-568

54. Natali P G, Bigotti A, Nicotra M R, et al. Analysis of the antigenic profile of uveal melanoma lesions with anti-cutaneous melanoma-associated antigen and anti-HLA monoclonal antibodies. Cancer Res. 1989;49:1269-1274

55. Cerny T, Owens S E, Mackenzie S A, et al. Immunoscintigraphy with $99 \mathrm{mTc}$ labelled $\mathrm{F}\left(\mathrm{ab} \mathrm{b}^{\prime}\right) 2$ fragments of an anti melanoma monoclonal antibody (225.28S) in patients with metastatic malignant melanoma. Eur J Nucl Med. 1987;13:130-133

56. Schrappe M, Klier F G, Spiro R C, Waltz T A, Reisfeld R A and Gladson C L. Correlation of chondroitin sulfate proteoglycan expression on proliferating brain capillary endothelial cells with the malignant phenotype of astroglial cells. Cancer Res. 1991;51:4986-4993

57. Kageshita T, Nakamura T, Yamada M, Kuriya N, Arao T and Ferrone S. Differential expression of melanoma associated antigens in acral lentiginous melanoma and in nodular melanoma lesions. Cancer Res. 1991;51:1726-1732

58. Kageshita T, Yamada M, Arao T and Ferrone S. Expression of high molecular weight-melanoma associated antigen (HMW-MAA) in primary ALM lesions is associated with a poor prognosis. Pigment Cell Res. 1992;Suppl 2:132-135

59. Kageshita T, Kuriya N, Ono T, et al. Association of high molecular weight melanoma-associated antigen expression in primary acral lentiginous melanoma lesions with poor prognosis. Cancer Res. 1993;53:2830-2833

60. Shoshan Y, Nishiyama A, Chang A, et al. Expression of oligodendrocyte progenitor cell antigens by gliomas: implications for the histogenesis of brain tumors. Proc Natl Acad Sci USA. 1999:96:10361-10366

61. Chekenya M, Rooprai H K, Davies D, Levine J M, Butt A M and Pilkington G J. The NG2 chondroitin sulfate proteoglycan: role in malignant progression of human brain tumours. Int J Dev Neurosci. 1999;17:421-435

62. Chekenya M, Enger P O, Thorsen F, et al. The glial precursor proteoglycan, NG2, is expressed on tumour neovasculature by vascular pericytes in human malignant brain tumours. Neuropathol Appl Neurobiol. 2002;28:367-380

63. Li Y, Madigan M C, Lai K, et al. Human uveal melanoma expresses NG2 immunoreactivity. Br J Ophthalmol. 2003;87:629-632

64. Dell'Erba L, Calo-Gabrieli G, Caruso M L, et al. Immunohistochemical reactivity of anti-melanoma monoclonal antibody 225.28S in human breast cancer biopsies. Anticancer Res. 2001;21:925-930

65. Schwab J H, Boland P J, Agaram N P, et al. Chordoma and chondrosarcoma gene profile: implications for immunotherapy. Cancer Immunol Immunother. 2009:58:339-349

66. Burns W R, Zhao Y, Frankel T L, et al. A high molecular weight melanoma-associated antigen-specific chimeric antigen receptor redirects lymphocytes to target human melanomas. Cancer Res. 2010;70:3027-3033

67. Nishi H, Inoue Y, Kageshita T, Takata M and Ihn H. The expression of human high molecular weight melanoma-associated antigen in acral lentiginous melanoma. Biosci Trends. 2010;4:86-89

68. Westekemper H, Karimi S, Susskind D, et al. Expression of MCSP and PRAME in conjunctival melanoma. Br J Ophthalmol. 2010;94:1322-1327

69. Svendsen A, Verhoeff J J, Immervoll $\mathrm{H}$, et al. Expression of the progenitor marker NG2/CSPG4 predicts poor survival and resistance to ionising radiation in glioblastoma. Acta Neuropathol. 2011;122:495-510

70. Wang J, Svendsen A, Kmiecik J, et al. Targeting the NG2/CSPG4 proteoglycan retards tumour growth and angiogenesis in preclinical models of GBM and melanoma. PLoS One. 2011;6:e23062

71. Hsu N C, Nien P Y, Yokoyama K K, Chu P Y and Hou M F. High chondroitin sulfate proteoglycan 4 expression correlates with poor outcome in patients with breast cancer. Biochem Biophys Res Commun. 2013;441:514-518

72. Goto Y, Arigami T, Murali R, et al. High molecular weight-melanoma-associated antigen as a biomarker of desmoplastic melanoma. Pigment Cell Melanoma Res. 2010;23:137-140

73. Lim S D, Stallcup W, Lefkove B, et al. Expression of the neural stem cell markers NG2 and L1 in human angiomyolipoma: are angiomyolipomas neoplasms of stem cells? Mol Med. 2007:13:160-165

74. Fawwaz R A, Wang T S, Estabrook A, et al. Immunoreactivity and biodistribution of indium-111-labeled monoclonal antibody to a human high molecular weight-melanoma associated antigen. J Nucl Med. 1985;26:488-492

75. Buraggi G L, Callegaro L, Mariani G, et al. Imaging with 131I-labeled monoclonal antibodies to a high-molecular-weight melanoma-associated antigen in patients with melanoma: efficacy of whole immunoglobulin and its $F\left(a b^{\prime}\right) 2$ fragments. Cancer Res. 1985;45:3378-3387

76. Schaling D F, van der Pol J P, Jager M J, van Kroonenburgh M J, Oosterhuis J A and Ruiter D J. Radioimmunoscintigraphy and immunohistochemistry with melanoma-associated monoclonal antibodies in choroidal melanoma: a comparison of the clinical and immunohistochemical results. Br J Ophthalmol. 1990;74:538-541

77. Temponi M, Fawwaz R A, Kekish U, Wang T S and Ferrone S. Improvement by affinity chromatography on antiidiotypic monoclonal antibodies (MAbs) of immunoreactivity and in vivo targeting of radiolabelled anti-HMW-MAA MAb TP61.5 in nude mice bearing human melanoma lesions. Int J Cancer. 1991;49:624-630

78. Hamby C V, Chinol M, Palestro C J, Manzo C and Ferrone S. Improved tumor targeting of rhenium-186-labeled anti-human high-m.w. melanoma-associated antigen monoclonal antibody 763.74 following purification with anti-idiotypic monoclonal antibody MK2-23. Int J Cancer. 1998;78:486-490

79. Kang N V, Hamilton S, Sanders R, Wilson G D and Kupsch J M. Efficient in vivo targeting of malignant melanoma by single-chain Fv antibody fragments. Melanoma Res. 1999;9:545-556

80. Kang N, Hamilton S, Odili J, Wilson G and Kupsch J. In vivo targeting of malignant melanoma by 125Iodine- and $99 \mathrm{mTechnetium-labeled} \mathrm{single-chain}$ Fv fragments against high molecular weight melanoma-associated antigen. Clin Cancer Res. 2000;6:4921-4931

81. Pacifico M D, Pearl R A and Kupsch J M. The use of a cocktail of single chain Fv antibody fragments to improve the in vitro and in vivo targeting of melanoma. J Exp Clin Cancer Res. 2006;25:45-53

82. Goto $\mathrm{Y}$, Ferrone $\mathrm{S}$, Arigami $\mathrm{T}$, et al. Human high molecular weight-melanoma-associated antigen: utility for detection of metastatic melanoma in sentinel lymph nodes. Clin Cancer Res. 2008;14:3401-3407

83. Vergilis I J, Szarek M, Ferrone S and Reynolds S R. Presence and prognostic significance of melanoma-associated antigens CYT-MAA and HMW-MAA in serum of patients with melanoma. J Invest Dermatol. 2005;125:526-531

84. Ulmer A and Fierlbeck G. Circulating tumor cells and detection of the melanoma-associated antigen HMW-MAA in the serum of melanoma patients. J Invest Dermatol. 2006;126:914-5; author reply 915-6

85. Kitago M, Koyanagi K, Nakamura $\mathrm{T}$, et al. mRNA expression and BRAF mutation in circulating melanoma cells isolated from peripheral blood with high molecular weight melanoma-associated antigen-specific monoclonal antibody beads. Clin Chem. 2009;55:757-764

86. Rao C, Bui $\mathrm{T}$, Connelly $\mathrm{M}$, et al. Circulating melanoma cells and survival in metastatic melanoma. Int J Oncol. 2011;38:755-760

87. Sakaizawa $\mathrm{K}$, Goto $\mathrm{Y}$, Kiniwa $\mathrm{Y}$, et al. Mutation analysis of BRAF and KIT in circulating melanoma cells at the single cell level. Br J Cancer. 2012;106:939-946

88. Freeman J B, Gray E S, Millward M, Pearce R and Ziman M. Evaluation of a multi-marker immunomagnetic enrichment assay for the quantification of circulating melanoma cells. J Transl Med. 2012;10:192-5876-10-192

89. Le Rhun E, Tu Q, De Carvalho Bittencourt M, et al. Detection and quantification of CSF malignant cells by the CellSearch technology in patients with melanoma leptomeningeal metastasis. Med Oncol. 2013;30:538-013-0538-3. Epub 2013 Mar 16

90. Natali P, Bigotti A, Cavaliere R, et al. Heterogeneous expression of melanoma-associated antigens and HLA antigens by primary and multiple metastatic lesions removed from patients with melanoma. Cancer Res. 1985;45:2883-2889

91. Burg M A, Grako K A and Stallcup W B. Expression of the NG2 proteoglycan enhances the growth and metastatic properties of melanoma cells. J Cell Physiol. 1998;177:299-312

92. Cooney C A, Jousheghany F, Yao-Borengasser A, et al. Chondroitin sulfates play a major role in breast cancer metastasis: a role for CSPG4 and CHST11 gene expression in forming surface P-selectin ligands in aggressive breast cancer cells. Breast Cancer Res. 2011;13:R58

93. Terp M G, Lund R R, Jensen O N, Leth-Larsen R and Ditzel H J. Identification of markers associated with highly aggressive metastatic phenotypes using quantitative comparative proteomics. Cancer Genomics Proteomics. 2012;9:265-273

94. Smith F O, Rauch C, Williams D E, et al. The human homologue of rat NG2, a chondroitin sulfate proteoglycan, is not expressed on the cell surface of normal hematopoietic cells but is expressed by acute myeloid leukemia blasts from poor-prognosis patients with abnormalities of chromosome band 11q23. Blood. 1996:87:1123-1133

95. Behm F G, Smith F O, Raimondi S C, Pui C H and Bernstein I D. Human homologue of the rat chondroitin sulfate proteoglycan, NG2, detected by monoclonal antibody 7.1, identifies childhood acute lymphoblastic leukemias with $\mathrm{t}(4 ; 11)(\mathrm{q} 21 ; \mathrm{q} 23)$ or $\mathrm{t}(11 ; 19)(\mathrm{q} 23 ; \mathrm{p} 13)$ and MLL gene rearrangements. Blood. 1996;87:1134-1139

96. Hilden J M, Smith F O, Frestedt J L, et al. MLL gene rearrangement, cytogenetic 11q23 abnormalities, and expression of the NG2 molecule in infant acute myeloid leukemia. Blood. 1997;89:3801-3805

97. Mauvieux L, Delabesse E, Bourquelot P, et al. NG2 expression in MLL rearranged acute myeloid leukaemia is restricted to monoblastic cases. $\mathrm{Br} \mathrm{J}$ Haematol. 1999;107:674-676

98. Wuchter C, Harbott J, Schoch C, et al. Detection of acute leukemia cells with mixed lineage leukemia (MLL) gene rearrangements by flow cytometry using monoclonal antibody 7.1. Leukemia. 2000:14:1232-1238 
99. Emerenciano M, Renaud G, Sant'Ana M, et al. Challenges in the use of NG2 antigen as a marker to predict MLL rearrangements in multi-center studies. Leuk Res. 2011;35:1001-1007

100. Zangrando A, Intini F, te Kronnie G and Basso G. Validation of NG2 antigen in identifying BP-ALL patients with MLL rearrangements using qualitative and quantitative flow cytometry: a prospective study. Leukemia. 2008;22:858-861

101. Schwartz S, Rieder H, Schlager B, Burmeister T, Fischer L and Thiel E. Expression of the human homologue of rat NG2 in adult acute lymphoblastic leukemia: close association with MLL rearrangement and a CD10(-)/CD24(-)/CD65s(+)/CD15(+) B-cell phenotype. Leukemia. 2003;17:1589-1595

102. Neudenberger J, Hotfilder M, Rosemann A, et al. Lack of expression of the chondroitin sulphate proteoglycan neuron-glial antigen 2 on candidate stem cell populations in paediatric acute myeloid leukaemia/abn(11q23) and acute lymphoblastic leukaemia/t(4;11). Br J Haematol. 2006;133:337-344

103. Burmeister T, Meyer C, Schwartz S, et al. The MLL recombinome of adult CD10-negative B-cell precursor acute lymphoblastic leukemia: results from the GMALL study group. Blood. 2009;113:4011-4015

104. Anargyrou K, Paterakis G, Boutsis D, et al. An unusual case of CD4+ CD7+ CD56+ acute leukemia with overlapping features of type 2 dendritic cell (DC2) and myeloid/NK cell precursor acute leukemia. Eur J Haematol. 2003;71:294-298

105. Drake A S, Brady M T, Wang X H, et al. Targeting 11q23 positive acute leukemia cells with high molecular weight-melanoma associated antigen-specific monoclonal antibodies. Cancer Immunol Immunother. 2009;58:415-427

106. Petrovici K, Graf M, Hecht K, Reif S, Pfister K and Schmetzer H. Use of NG2 (7.1) in AML as a tumor marker and its association with a poor prognosis. Cancer Genomics Proteomics. 2010;7:173-180

107. Bueno C, Montes R, Martin L, et al. NG2 antigen is expressed in CD34+ HPCs and plasmacytoid dendritic cell precursors: is NG2 expression in leukemia dependent on the target cell where leukemogenesis is triggered? Leukemia. 2008;22:1475-1478

108. Menendez P and Bueno C. Expression of NG2 antigen in MLL-rearranged acute leukemias: how complex does it get? Leuk Res. 2011;35:989-990

109. Persson A I, Petritsch C, Swartling F J, et al. Non-stem cell origin for oligodendroglioma. Cancer Cell. 2010;18:669-682

110. Al-Mayhani M T, Grenfell R, Narita M, et al. NG2 expression in glioblastoma identifies an actively proliferating population with an aggressive molecular signature. Neuro Oncol. 2011;13:830-845

111. Barrantes-Freer A, Kim E, Bielanska J, et al. Human glioma-initiating cells show a distinct immature phenotype resembling but not identical to NG2 glia. J Neuropathol Exp Neurol. 2013;72:307-324

112. Girolamo F, Dallatomasina A, Rizzi M, et al. Diversified expression of NG2/CSPG4 isoforms in glioblastoma and human foetal brain identifies pericyte subsets. PLoS One. 2013;8:e84883

113. Schmidt P, Kopecky C, Hombach A, Zigrino P, Mauch C and Abken H. Eradication of melanomas by targeted elimination of a minor subset of tumor cells. Proc Natl Acad Sci USA. 2011:108:2474-2479

114. Iida J, Skubitz A P, Furcht L T, Wayner E A and McCarthy J B. Coordinate role for cell surface chondroitin sulfate proteoglycan and alpha 4 beta 1 integrin in mediating melanoma cell adhesion to fibronectin. J Cell Biol. 1992;118:431-444

115. Iida J, Meijne A M, Spiro R C, Roos E, Furcht L T and McCarthy J B. Spreading and focal contact formation of human melanoma cells in response to the stimulation of both melanoma-associated proteoglycan (NG2) and alpha 4 beta 1 integrin. Cancer Res. 1995:55:2177-2185

116. Fukushi J, Makagiansar I T and Stallcup W B. NG2 proteoglycan promotes endothelial cell motility and angiogenesis via engagement of galectin-3 and alpha3beta1 integrin. Mol Biol Cell. 2004;15:3580-3590

117. Yu L, Favoino E, Wang Y, Ma Y, Deng X and Wang X. The CSPG4-specific monoclonal antibody enhances and prolongs the effects of the BRAF inhibitor in melanoma cells. Immunol Res. 2011;50:294-302

118. Schlingemann $\mathrm{R} O$, Rietveld F J, de Waal R M, Ferrone S and Ruiter D J. Expression of the high molecular weight melanoma-associated antigen by pericytes during angiogenesis in tumors and in healing wounds. Am J Pathol. 1990;136:1393-1405

119. Ozerdem U. . Targeting pericytes diminishes neovascularization in orthotopic uveal melanoma in nerve/glial antigen 2 proteoglycan knockout mouse. Ophthalmic Res. 2006;38:251-254

120. Huang F J, You W K, Bonaldo P, Seyfried T N, Pasquale E B and Stallcup W B. Pericyte deficiencies lead to aberrant tumor vascularizaton in the brain of the NG2 null mouse. Dev Biol. 2010;344:1035-1046

121. Goretzki L, Lombardo C R and Stallcup W B. Binding of the NG2 proteoglycan to kringle domains modulates the functional properties of angiostatin and plasmin(ogen). J Biol Chem. 2000;275:28625-28633

122. Song S, Ewald A J, Stallcup W, Werb Z and Bergers G. PDGFRbeta+ perivascular progenitor cells in tumours regulate pericyte differentiation and vascular survival. Nat Cell Biol. 2005;7:870-879

123. Gibby K, You W K, Kadoya K, et al. Early vascular deficits are correlated with delayed mammary tumorigenesis in the MMTV-PyMT transgenic mouse following genetic ablation of the NG2 proteoglycan. Breast Cancer Res. 2012;14:R67

124. Ozerdem U and Stallcup W B. Early contribution of pericytes to angiogenic sprouting and tube formation. Angiogenesis. 2003;6:241-249
125. Tigges U, Hyer E G, Scharf J and Stallcup W B. FGF2-dependent neovascularization of subcutaneous Matrigel plugs is initiated by bone marrow-derived pericytes and macrophages. Development. 2008;135:523-532

126. Ozerdem U and Stallcup W B. Pathological angiogenesis is reduced by targeting pericytes via the NG2 proteoglycan. Angiogenesis. 2004;7:269-276

127. Rajantie I, Ilmonen M, Alminaite A, Ozerdem U, Alitalo K and Salven P. Adult bone marrow-derived cells recruited during angiogenesis comprise precursors for periendothelial vascular mural cells. Blood. 2004;104:2084-2086

128. Virgintino D, Girolamo F, Errede M, et al. An intimate interplay between precocious, migrating pericytes and endothelial cells governs human fetal brain angiogenesis. Angiogenesis. 2007;10:35-45

129. Virgintino D, Ozerdem U, Girolamo F, Roncali L, Stallcup W B and Perris R. Reversal of cellular roles in angiogenesis: implications for anti-angiogenic therapy. J Vasc Res. 2008;45:129-131

130. Zhang H, Bie P, Leida Z, Xia Z and Bai L. NG2/CSPG4 Proteoglycan as a Novel Prognostic Indicator and Therapeutic Target in Malignant Cancer. J Stem Cell Res Ther. 2014;4:171

131. Bumol T F, Wang Q C, Reisfeld R A and Kaplan N O. Monoclonal antibody and an antibody-toxin conjugate to a cell surface proteoglycan of melanoma cells suppress in vivo tumor growth. Proc Natl Acad Sci USA. 1983;80:529-533

132. Matsui M, Nakanishi $T$, Noguchi $T$, Imai $K$, Yachi A and Ferrone S Suppression of human melanoma growth in nude mice injected with anti high-molecular-weight melanoma-associated antigen monoclonal antibody 225.28S conjugated to purothionin. Jpn J Cancer Res. 1985;76:119-123

133. Ghose T, Ferrone S, Blair A H, et al. Regression of human melanoma xenografts in nude mice injected with methotrexate linked to monoclonal antibody 225.28 to human high molecular weight-melanoma associated antigen. Cancer Immunol Immunother 1991:34:90-96

134. Tordsson J M, Ohlsson L G, Abrahmsen L B, Karlstrom P J, Lando P A and Brodin T N. Phage-selected primate antibodies fused to superantigens for immunotherapy of malignant melanoma. Cancer Immunol Immunother. 2000:48:691-702

135. Hafner C, Breiteneder H, Ferrone S, et al. Suppression of human melanoma tumor growth in SCID mice by a human high molecular weight-melanoma associated antigen (HMW-MAA) specific monoclonal antibody. Int J Cancer. 2005;114:426-432

136. Rizvi S M, Qu C F, Song Y J, Raja C and Allen B J. In vivo studies of pharmacokinetics and efficacy of Bismuth-213 labeled antimelanoma monoclonal antibody 9.2.27. Cancer Biol Ther. 2005;4:763-768

137. Wagner S, Krepler C, Allwardt D, et al. Reduction of human melanoma tumor growth in severe combined immunodeficient mice by passive transfer of antibodies induced by a high molecular weight melanoma-associated antigen mimotope vaccine. Clin Cancer Res. 2008;14:8178-8183

138. de Bruyn M, Rybczynska A A, Wei Y, et al. Melanoma-associated Chondroitin Sulfate Proteoglycan (MCSP)-targeted delivery of soluble TRAIL potently inhibits melanoma outgrowth in vitro and in vivo. Mol Cancer. 2010;9:301-4598-9-301

139. Wang X, Katayama A, Wang Y, et al. Functional characterization of an scFv-Fc antibody that immunotherapeutically targets the common cancer cell surface proteoglycan CSPG4. Cancer Res. 2011;71:7410-7422

140. Kaufmann J K, Bossow S, Grossardt C, et al. Chemovirotherapy of malignant melanoma with a targeted and armed oncolytic measles virus. J.Invest.Dermatol. 2013;133:1034-1042

141. Maciag P C, Seavey M M, Pan Z K, Ferrone S and Paterson Y. Cancer immunotherapy targeting the high molecular weight melanoma-associated antigen protein results in a broad antitumor response and reduction of pericytes in the tumor vasculature. Cancer Res. 2008;68:8066-8075

142. You W K, Yotsumoto F, Sakimura K, Adams R H and Stallcup W B. NG2 proteoglycan promotes tumor vascularization via integrin-dependent effects on pericyte function. Angiogenesis. 2014;17:61-76

143. Guan Y Y, Luan X, Xu J R, et al. Selective eradication of tumor vascular pericytes by peptide-conjugated nanoparticles for antiangiogenic therapy of melanoma lung metastasis. Biomaterials. 2014;35:3060-3070

144. Geldres C, Savoldo B, Hoyos V, et al. T lymphocytes redirected against the chondroitin sulfate proteoglycan- 4 control the growth of multiple solid tumors both in vitro and in vivo. Clin Cancer Res. 2014:20:962-971

145. Schrappe M, Bumol T F, Apelgren L D, et al. Long-term growth suppression of human glioma xenografts by chemoimmunoconjugates of 4-desacetylvinblastine-3-carboxyhydrazide and monoclonal antibody 9.2.27. Cancer Res. 1992;52:3838-3844

146. Hjortland G O, Garman-Vik S S, Juell S, et al. Immunotoxin treatment targeted to the high-molecular-weight melanoma-associated antigen prolonging the survival of immunodeficient rats with invasive intracranial human glioblastoma multiforme. J Neurosurg. 2004;100:320-327

147. Poli A, Wang J, Domingues O, et al. Targeting glioblastoma with NK cells and $\mathrm{mAb}$ against NG2/CSPG4 prolongs animal survival. Oncotarget. 2013;4:1527-1546

148. Pfosser A, Brandl M, Salih H, Grosse-Hovest L and Jung G. Role of target antigen in bispecific-antibody-mediated killing of human glioblastoma cells: a pre-clinical study. Int J Cancer. 1999;80:612-616

149. Ruf P, Jager M, Ellwart J, Wosch S, Kusterer E and Lindhofer H. Two new trifunctional antibodies for the therapy of human malignant melanoma. Int J Cancer. 2004;108:725-732

150. Bluemel C, Hausmann S, Fluhr P, et al. Epitope distance to the target cell membrane and antigen size determine the potency of $\mathrm{T}$ cell-mediated lysis by 
BiTE antibodies specific for a large melanoma surface antigen. Cancer Immunol Immunother. 2010;59:1197-1209

151. Torisu-Itakura H, Schoellhammer H F, Sim M S, et al. Redirected lysis of human melanoma cells by a MCSP/CD3-bispecific BiTE antibody that engages patient-derived T cells. J Immunother. 2011;34:597-605

152. Dummer R, Mittelman A, Fanizzi F P, Lucchese G, Willers J and Kanduc D. Non-self-discrimination as a driving concept in the identification of an immunodominant HMW-MAA epitopic peptide sequence by autoantibodies from melanoma cancer patients. Int J Cancer. 2004;111:720-726

153. Peng L, Ko E, Luo W, Wang X, Shrikant P A and Ferrone S. CD4-dependent potentiation of a high molecular weight-melanoma-associated antigen-specific CTL response elicited in $\mathrm{HLA}-\mathrm{A} 2 / \mathrm{Kb}$ transgenic mice. J Immunol. 2006; $176: 2307-2315$

154. Erfurt C, Sun Z, Haendle I, et al. Tumor-reactive CD4+ T cell responses to the melanoma-associated chondroitin sulphate proteoglycan in melanoma patients and healthy individuals in the absence of autoimmunity. J Immunol. 2007;178:7703-7709

155. Erfurt C, Muller E, Emmerling S, et al. Melanoma-associated chondroitin sulphate proteoglycan as a new target antigen for CD4+ T cells in melanoma patients. Int J Cancer. 2009;124:2341-2346

156. Luo W, Ko E, Hsu J C, Wang X and Ferrone S. Targeting melanoma cells with human high molecular weight-melanoma associated antigen-specific antibodies elicited by a peptide mimotope: functional effects. J Immunol. 2006;176:6046-6054

157. Wagner S, Hafner C, Allwardt D, et al. Vaccination with a human high molecular weight melanoma-associated antigen mimotope induces a humoral response inhibiting melanoma cell growth in vitro. J Immunol. 2005; $174: 976-982$

158. Mittelman A, Chen Z J, Kageshita T, et al. Active specific immunotherapy in patients with melanoma. A clinical trial with mouse antiidiotypic monoclonal antibodies elicited with syngeneic anti-high-molecular-weight-melanoma-associated antigen monoclonal antibodies. J Clin Invest. 1990;86:2136-2144

159. Chattopadhyay P, Kaveri S V, Byars N, Starkey J, Ferrone S and Raychaudhuri S. Human high molecular weight-melanoma associated antigen mimicry by an anti-idiotypic antibody: characterization of the immunogenicity and the immune response to the mouse monoclonal antibody IMel-1. Cancer Res. 1991:51:6045-6051

160. Murray J L, Gillogly M, Kawano K, et al. Fine specificity of high molecular weight-melanoma-associated antigen-specific cytotoxic $\mathrm{T}$ lymphocytes elicited by anti-idiotypic monoclonal antibodies in patients with melanoma. Cancer Res. 2004;64:5481-5488

161. Wang X, Ko E C, Peng L, Gillies S D and Ferrone S. Human high molecular weight melanoma-associated antigen mimicry by mouse anti-idiotypic monoclonal antibody MK2-23: enhancement of immunogenicity of anti-idiotypic monoclonal antibody MK2-23 by fusion with interleukin 2. Cancer Res. 2005;65:6976-6983

162. Cheever M A, Allison J P, Ferris A S, et al. The prioritization of cancer antigens: a national cancer institute pilot project for the acceleration of translational research. Clin Cancer Res. 2009;15:5323-5337

163. Chang C C, Hernandez-Guzman F G, Luo W, Wang X, Ferrone S and Ghosh D. Structural basis of antigen mimicry in a clinically relevant melanoma antigen system. J Biol Chem. 2005;280:41546-41552

164. Mittelman A, Chen Z J, Yang H, Wong G Y and Ferrone S. Human high molecular weight melanoma-associated antigen (HMW-MAA) mimicry by mouse anti-idiotypic monoclonal antibody MK2-23: induction of humoral anti-HMW-MAA immunity and prolongation of survival in patients with stage IV melanoma. Proc Natl Acad Sci USA. 1992:89:466-470

165. Mittelman A, Chen Z J, Liu C C, Hirai S and Ferrone S. Kinetics of the immune response and regression of metastatic lesions following development of humoral anti-high molecular weight-melanoma associated antigen immunity in three patients with advanced malignant melanoma immunized with mouse antiidiotypic monoclonal antibody MK2-23. Cancer Res. 1994;54:415-421

166. Mittelman A, Chen G Z, Wong G Y, Liu C, Hirai S and Ferrone S. Human high molecular weight-melanoma associated antigen mimicry by mouse anti-idiotypic monoclonal antibody MK2-23: modulation of the immunogenicity in patients with malignant melanoma. Clin Cancer Res. 1995;1:705-713

167. Keleg S, Titov A, Heller A, et al. Chondroitin sulfate proteoglycan CSPG4 as a novel hypoxia-sensitive marker in pancreatic tumors. PLoS One. 2014;9:e100178. 